III non-small cell lung cancer: randomized phase III trial RTOG 9410. J Natl Cancer Inst. 2011;103(19):1452-1460. doi:10.1093/jnci/djr325

3. Liang J, Bí N, Wu $\mathbf{S}$, et al. Etoposide and cisplatin versus paclitaxel and carboplatin with concurrent thoracic radiotherapy in unresectable stage III non-small cell lung cancer: a multicenter randomized phase III trial. Annals of Oncology. 2017;28(4):777-783. doi:10.1093/annonc/mdx009

4. Boyle J, Ackerson B, Gu L, Kelsey CR. Dosimetric advantages of intensity modulated radiation therapy in locally advanced lung cancer. Adv Radiat Oncol. 2017;2(1):6-11. doi:10.1016/j.adro.2016.12.006

5. Đinh Công Định. "Đánh giá kết quả điều trị ung thư phổi không tế bào nhó giai đoạn III bằng hóa chất kết hợp xa trị VMAT tai Bênh viên K." Luân văn thạc sĩ y học, Trường đại học Y Hà Nội.:2020.
6. Lê Thi Yến. Đánh giá kết quả hóa xa tri đồng thờ phác đồ paclitaxel - carboplatin trong ung thư phổi không tê bào nhỏ giai đoan IIIB tai Bênh viên $\mathrm{K}$. Luận án tiến sĩ y học, Trường đại học Y Hă Nội. 2019.

7. Lê Tuấn Anh. "Hóa-xa trị đồng thời ung thư phổi không tế bào nhỏ giai đoạn III." Luận án tiến sĩ y học, Trường đại học Y Dược TP Hồ Chí Minh. Published online 2015.

8. Hàng Quốc Tuấn và cs. Đánh giá kết quả điều trị ung thư phổi không tế bào nhỏ giai đoạn III không mố được bằng phác đồ hóa chất PaclitaxelCarboplatin kết hợp hóa xa đồng thời . Tap chí ung thư hoc Viêt Nam, 4, 68-75. Published online 2020.

9. Palma DA, Senan $S$, Tsujino $K$, et al. Predicting radiation pneumonitis after chemoradiation therapy for lung cancer: an international individual patient data meta-analysis. Int J Radiat Oncol Biol Phys. 2013; 85(2):444-450. doi:10.1016/ j.ijrobp.2012.04.043

\title{
KIẾN THỨC VÀ HÀNH VI TÌNH DUUC AN TOÀN CỦA NGƯỜI DI CƯ LAO ĐộNG TỰ DO TAI PHƯỜNG HOÀNG LIẸTT, QUÂ̂N HOÀNG MAI, THẦNH PHỐ HÀ NộI NĂM 2021
}

\author{
Trần Thị Thanh Thủy ${ }^{1}$, Nguyễn Ngọc Kiều $\mathrm{Anh}^{2}$
}

\section{TÓM TẮT}

Kết quả: Điều tra mô tả cắt ngang trên 209 đối tượng là người di cư lao động tự do tại phường Hoàng Liệt, quận Hoàng Mai, Hà Nội năm 2021 nhằm mô tả kiến thức và hành vi tình dục an toàn và môt số yếu tố liên quan. Chọn mẫu theo phương pháp thuận tiện và Snowball Sampling, sử dung bố công cư tư điền khuyết danh để thu thập số liệu. Kết quả nghiển cứu cho thấy người di cư lao động tự do có kiến thức tình dục an toàn đạt khá cao chiếm $70,33 \%$. Tuy nhiên kiến thức về thời điểm dế có thai nhất trong chu kỳ kinh nguyệt khá thấp (35\% nam và $58 \%$ nữ). Các đối tương tham gia nghiên cứu đã nghe nói về tình dục an toàn, nhưng để hiểu về tình dục an toàn còn chưa được cao.

Tư khoá: Tình dục an toàn, di cư, lao động tự do, Hà Nô̂i.

\section{SUMMARY \\ KNOWLEDGE AND BEHAVIOURS OF SAFE SEX OF FREELANCE WORKERS IN HOANG LIET WARD, HOANG MAI DISTRICT, HANOI CITY IN 2021}

A cross-sectional study was conducted on 209 subjects freelance migrant workers in Hoang Liet ward, Hoang Mai district, Hanoi in 2021 for the purpose of describing knowledge and total sexual

*Trường Đại học Y Hà Nội

Chịu trách nhiệm chính: Trân Thị Thanh Thủy

Email: Tranthanhthuy@hmu.edu.vn

Ngày nhận bài: 29.7.2021

Ngày phản biên khoa họ: 29.9.2021

Ngày duyệt bài: 4.10.2021 behavior and a number of important factor links. Select the sample by the method and Snowball Sampling, use the anonymous tooler to collect the data. Research results for self-employed workers show that having full educational knowledge is quite high, accounting for $70.33 \%$. However, knowledge about the most fertile time in the menstrual cycle is quite low (35\% of men and $58 \%$ of women). Study of the whole population, the subjects had heard about the education landscape, but their understanding of the education landscape was not very high.

Keywords: safe sex, migration, freelance workers, Hanoi

\section{I. ĐĂT VẤN ĐỀ}

Theo thống kê đến giữa năm 2019, số người di cư toàn cầu là 271,6 triệu người, tăng 0,7 điểm so với năm 20001, điều này chứng tỏ nhu cầu tìm việc làm, nơi ở mới, môi trường giáo dục mới không ngừng tăng cao, thu hút đông đảo nguồn lực cũng như chất xám đổ về những khu vực, quốc gia phát triển kinh tế, văn hoá, xã hội mạnh. Trong làn sóng lao động di cư thì đối tượng lao động tự do đang chiếm đông đảo và ngày một tăng mạnh, đặc biệt trong các ngành dịch vụ. Đây cũng là đối tượng mà gân đây được xã hội quan tâm hơn cả bởi toàn bộ lao động này đều không có hợp đồng lao động, cũng có nghĩa là họ không có hoặc phải tự xoay xở để có được môt loat quyền lợi cơ bản của người đi làm: Bảo hiểm xã hội dành cho hưu bổng, bảo hiểm thất nghiệp khi không có việc làm. Những khó khăn về kinh tế, xã hội thì những người di 
cư còn phải đối mặt với những khó khăn về sức khoẻ cả thể chất lẫn tinh thần. Việc xa quê hương, người thân yêu khiến họ dễ có cảm giác thiếu thốn về măt tình cảm. Bởi lẽ đó, ho sẽ có nhu cầu tìm đến những cách khác nhau để làm vơi đi sự thiếu thốn tinh thần và một trong những khía cạnh họ tìm đến là tình dục. Điều này cũng đồng nghĩa ngày càng nhiêu người trẻ di cư dễ mắc các bệnh lây truyền qua đường tình dục và nạo phá thai không an toàn3. Nghiên cứu gần đây cho thấy, tỷ lệ tử vong toàn cầu liên quan đến STIs ước tính bao gồm $200.000 \mathrm{ca}$ tử vong ở thai nhi và sơ sinh mỗi năm do giang mai và hơn 280.000 ca tử vong do ung thư cổ tử cung mỗi năm do HPV4. Hơn 1 triệu bệnh nhiễm trùng lây truyền qua đường tình dục (STIs) mắc phải mỗi ngày trên toàn thế giới 5 . Riêng tại Hà Nội tính đến năm 2013, có 20.972 người nhiễm HIV hiện đang còn sống, số bệnh nhân AIDS hiện còn sống là 5.271 và 3.808 trường hợp tử vong do AIDS6. Từ đó, cho thấy hiểu biết về sử dụng các biện pháp an toàn về tình dục vẫn còn thấp. Một trong số đó là quan hệ tình dục (QHTD) không an toàn, thiếu kiến thức về các biện pháp tránh thai (BPTT), các bệnh LTQĐTD ${ }^{1}$. Mắc dù đã có những nghiên cứu về tình dục ở thanh niên nói chung hay ở những người di cư lao động tại các khu công nghiệp nhưng rất ít nghiên cứu đề cập đến tình dục an toàn cho người di cư lao động tự do. Trong khi đó, những đối tượng di cư lao động tự do này lại là những đối tượng có nguy cơ cao do tính chất nghề dịch vụ thường tiếp xúc với nhiều người, thời gian làm việc không cố định, nơi ở không cố định. Chính vì vậy, chúng tôi tiến hành nghiên cứu: Kiến thức và hành vi tình dục an toàn của người di cư lao động tự do tại phường Hoàng Liêtt, quân Hoàng Mai, Thành phố Hà Nối năm 2021"

\section{II. ĐỐI TƯỢNG VÀ PHƯƠNG PHÁP NGHIÊN CỨU}

Đối tượng nghiên cứu: Đối tượng nghiên cứu bao gồm những người di cư lao động tự do đang sinh sống từ 6 tháng trở lên trên địa bàn phường Hoàng Liệt, quận Hoàng Mai, Thành phố Hà Nội.

- Thời gian nghiên cứu: Từ tháng 12/2020 đến tháng 06/2021

- Địa điểm nghiên cứu: Phường Hoàng Liệt, quận Hoàng Mai, Thành phố Hà Nội.

- Thiết kế nghiên cứu: Nghiên cứu mô tả cắt ngang

- Cõ mẫu:

$-\mathrm{n}=\mathrm{Z}_{1-\mathrm{a} / 2} \frac{p(1-p)}{(p \cdot \varepsilon)^{2}}$

Trong đó: $\mathrm{n}$ : cõ̃ mẫu nghiên cứu cần có
Z: hệ số tin cậy = 1,96 (mức ý nghĩa thống kê lấy $a=0,05$ ).

- p: Tỷ lệ kiến thức đạt về TDAT của người di cư lao động tự do trên địa bàn phường Hoàng Liệt, quận Hoàng Mai, thành phố Hà Nội, $p=$ 0,67 (Nghiên cứu thử 30 đối tượng với bộ câu hỏi (phụ lục 1) với tiêu chuẩn đánh giá được tham khảo từ một số nghiên cứu của Nguyển Lan $\mathrm{Anh}^{2}$ tại trường Cao đẳng nghề Việt - Hàn (2017); nghiên cứu của Phạm Thị Hương Trà Linh và Lã Ngọc Quang ${ }^{3}$ tại trường Cao đẳng Y tễ Phú Thọ (2015); nghiên cứu của Nguyễn Thị Phương trên đối tượng là nam công nhân chưa kết hôn di cư tại KCN Bình Xuyên, Vĩnh Phúc (2012) và nghiên cứu của Đặng Thị Chinh trên đối tượng là nam, nữ công nhân di cư tại $\mathrm{KCN}$ Samsung, Bắc Ninh (2020).

- $\varepsilon$ : là mức sai lệch tương đối giữa tỷ lệ thu được từ mẫu và tỷ lệ thu được từ quần thể. Lấy $\varepsilon=0,1$

- Từ đó ta có:

Ước tính cỡ mẫu: $\mathrm{n}=\frac{0,67 \times 0,33 \times 1,96^{2}}{(0,1 \times 0,67)^{2}}=189$

- Ta tính được cỡ mẫu tối thiểu cần cho nghiên cứu là $n=189$. Sau khi cộng thêm $10 \%$ bỏ cuộc, cõ mẫu cuối cùng được làm tròn là 210 đối tượng nghiên cứu. Trên thực tế đã thu được 209 mẫu nghiên cứu.

Phương pháp chọn mẫu: Nghiên cứu sử dụng phương pháp chọn mẫu thuận tiện và Snowball Sampling. Lựa chọn đối tượng là người di cư lao động tự do đang sinh sống tại địa bàn phường Hoàng Liệt có đủ tiêu chí lựa chọn tham gia vào nghiên cứu.

Thu thập tuỳ vào thời gian thuận tiện của đối tượng phỏng vấn.

Kỹ thuật và công cư thu thập số liệu: Nghiên cứu định lượng, điều tra viên gặp trực tiếp đối tượng nghiển cứu bày tỏ lý do nghiển cứu. Khi đổi tượng đồng ý tham gia nghiên cứu sẽ ký vào giấy đồng ý tham gia nghiên cứu thì điều tra viên sẽ phát phiếu trả lời để đối tượng tự điền vào bộ câu hỏi được thiết kế sẵn khuyết danh. Phỏng vấn theo bộ cầu hỏi tự điền thiết kế sẵn (phụ lục 1). Bộ câu hỏi được xây dựng trên cơ sở kiến thức trong tài liệu Hướng dấn Quốc gia về các dịch vụ chăm sóc sức khỏe sinh sản, 2009 của Bộ Y tế. Được chỉnh sửa cho phù hợp với mục tiêu nghiên cứu của đề tài và tình hình thực tế tại địa điểm nghiên cứu trước khi tiến hành khảo sát chính thức.

Xử lý và Phân tích số liệu: Số liệu được làm sạch và xử lý thông tin trền các phiếu điều tra trước khi nhập liệu bằng phần mềm Redcap. 
Số liệu được nhập và sau đó phân tích bằng phần mềm Stata 15.

Đạo đức nghiên cứu. Nghiên cứu được sự chấp thuận thông qua hội đồng đề cương nghiên cứu tại Bộ môn Dân số học, trường Đại học Y HN.

Đối tượng nghiên cứu được giải thích rõ về mục đích, nội dung nghiên cứu; chỉ phỏng vấn những đối tượng đủ tiêu chuẩn đồng ý tham gia nghiên cứu; đối tượng tham gia trên tinh thần tự nguyện và có quyền từ chối trả lời không tham gia vào bất cứ thời điểm nào.

Kết quả nghiên cứu, ý kiến đề xuất được sử dụng vào mục đích nâng cao sức khoẻ, hạn chế sự xuất hiện và tiến triển của bệnh cho cộng đồng.

\section{KẾT QUẢ NGHIÊN CỨU}

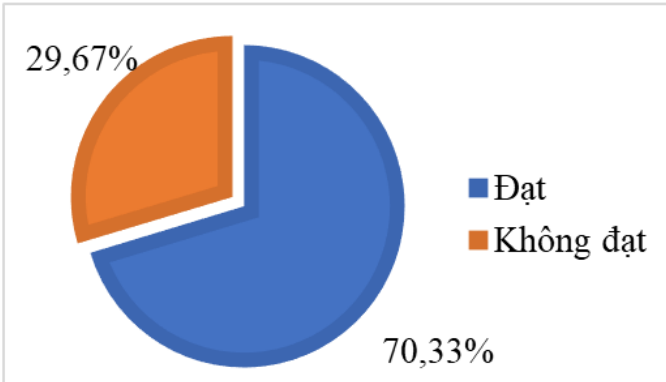

Biểu đồ 2. Kiến thức TDAT của người di cư lao động tự do

Kiến thức chung của lao động tự do di cư về tình dục an toàn khá cao với 70,33\% có kiến thức đạt trên tổng số 209 đối tượng tham gia nghiên cứu.

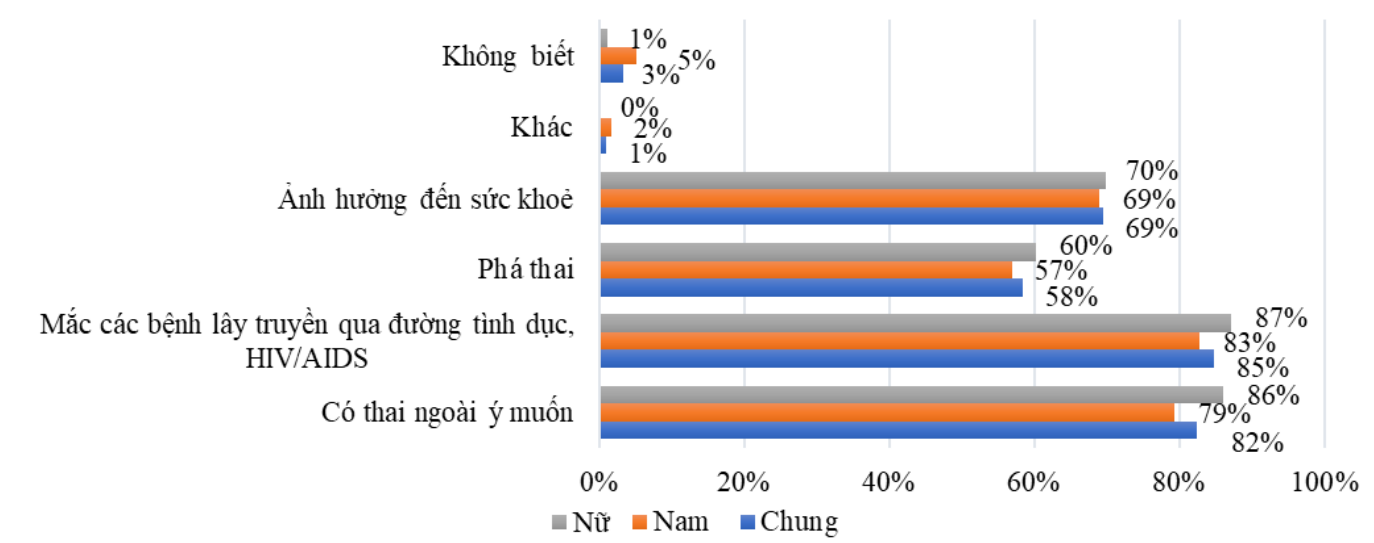

Biểu đồ 3. Kiến thức về hậu quả QHTD không an toàn

Có $79 \%$ ở nam và $86 \%$ ở nữ hiểu rằng QHTD không an toàn có thể gây có thai ngoài ý muốn, $87 \%$ ở nữ giới và $83 \%$ ở nam biết QHTD không an toàn dẫn đến mắc các bệnh LTQĐTD, HIV/AIDS.

\section{Bảng 1. Kiến thức về tình dục an toàn}

\begin{tabular}{|c|c|c|c|c|c|c|c|}
\hline \multirow{3}{*}{\multicolumn{2}{|c|}{ Yếu tố }} & \multicolumn{6}{|c|}{ Giới tinh } \\
\hline & & \multicolumn{2}{|c|}{ Nam } & \multicolumn{2}{|c|}{ Nũ̃ } & \multicolumn{2}{|c|}{ Tống } \\
\hline & & lượng & (\%) & lượng & $(\%)$ & lượng & $(\%)$ \\
\hline \multirow{3}{*}{$\begin{array}{l}\text { Đã nghe } \\
\text { về TDAT }\end{array}$} & Đã nghe & 106 & 91,38 & 88 & 94,62 & 194 & 92,82 \\
\hline & Chưa nghe & 10 & 8,62 & 5 & 5,38 & 15 & 7,18 \\
\hline & Sứ dụng BCS khi QHTD & 97 & 83,62 & 81 & 87,10 & 178 & 85,17 \\
\hline \multirow{3}{*}{$\begin{array}{l}\text { Hiểu về } \\
\text { tình dục } \\
\text { an toàn }\end{array}$} & $\begin{array}{l}\text { Không đế mang thai ngoài } \\
\text { ý muốn }\end{array}$ & 53 & 45,69 & 51 & 54,84 & 104 & 49,76 \\
\hline & $\begin{array}{l}\text { Không đế bị các bênh } \\
\text { LTQĐTD và HIV }\end{array}$ & 67 & 57,76 & 64 & 68,82 & 131 & 62,68 \\
\hline & Chỉ QHTD với một người & 56 & 42,28 & 43 & 46,24 & 99 & 47,37 \\
\hline
\end{tabular}

Có $83,62 \%$ nam di cư và $87,10 \%$ nữ di cư được hỏi trả lời tình dục an toàn là sử dụng BCS khi QHTD. Nữ giới có vẻ quan tâm nhiều đến việc có thai hay không, và $54,84 \%$ hiểu TDAT là không để mang thai ngoài ý muốn, trong khi đó, chỉ có $45,69 \%$ nam giới hiểu. Tiếp đó, việc hiểu không để bị các bệnh LTQĐTD ở nam chiếm $57,76 \%$ và nữ chiếm $68,82 \%$. Nhận thức chỉ

QHTD với một người có tỉ lệ thấp nhất, nam chiếm $42,28 \%$ và nữ $46,24 \%$. QHTD với một người có tỉ lệ thấp nhất, nam chiếm $42,28 \%$ và nữ 46,24\%. 35\% lao động nam hiểu đúng về thời điểm dễ mang thai là giữa hai kỳ kinh còn trong khi đó tỷ lệ này ở lao động nữ chiếm tới $58 \%$. Nam giới coi vấn đề liên quan đến chu kỳ kinh nguyệt chỉ nữ giới mới cần biết. 


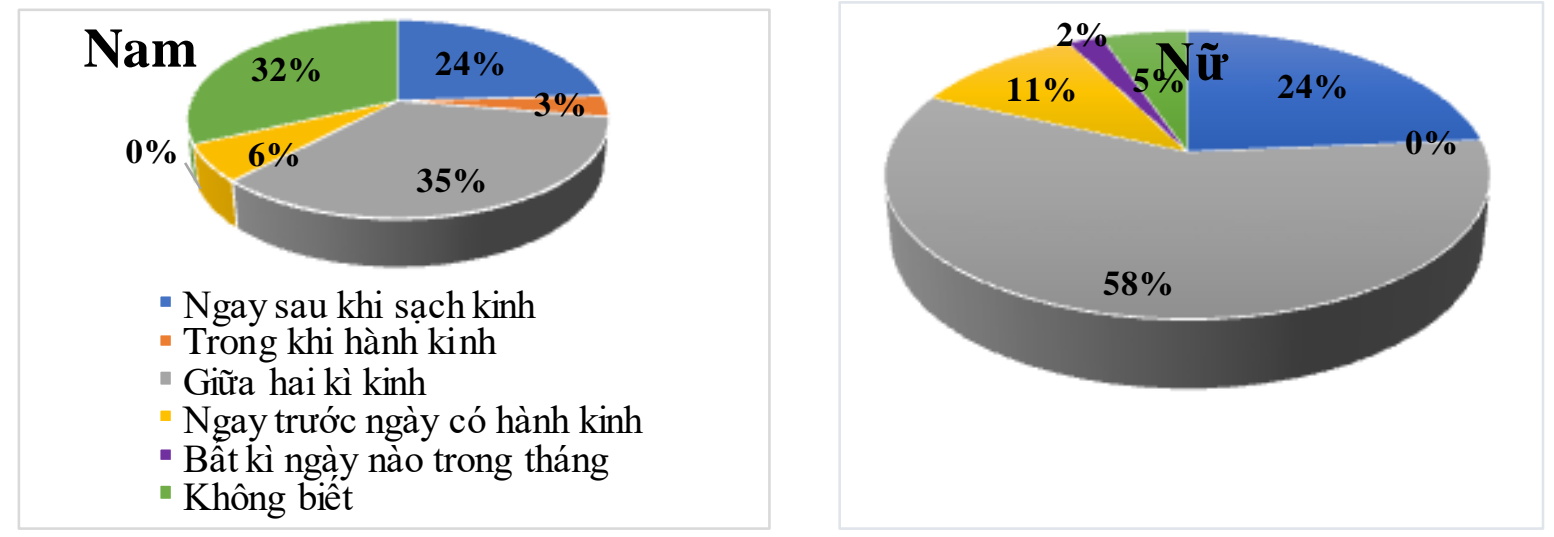

Biểu đồ 3. Kiến thức của người di cư lao động tự do về thời điểm dễ mang thai.

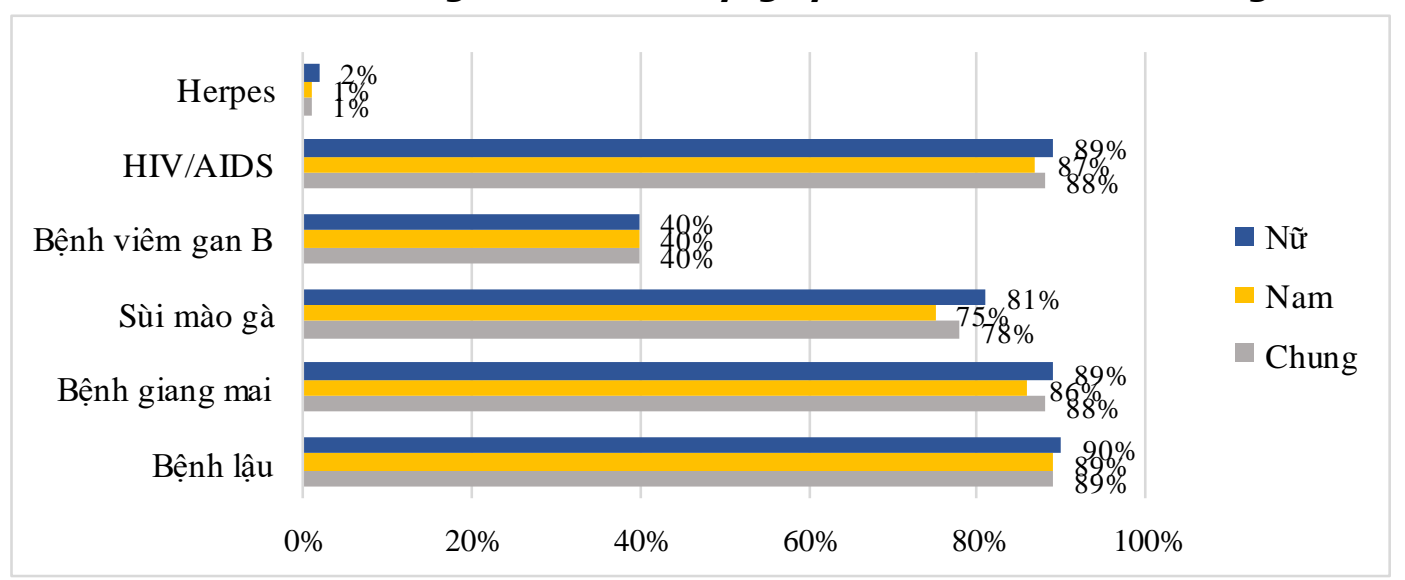

Biểu đồ 4. Kiên thức của lao động tự do di cư về những bệnh LTQĐTD

Đa số đối tượng tham gia nghiên cứu đều đã từng nghe nói đến bệnh lây truyền qua đường tình dục. Trong số những người đã biết về STIs, $100 \%$ biết ít nhất 1 tên bệnh. Ba bênh được lao động tự do di cư biết đến nhiều nhất là bệnh lậu, HIV/AIDS và bệnh giang mai đều chiếm gần $90 \%$. Tiếp đến là sùi mào gà chiếm gần $80 \%$. Riêng viêm gan $B$, tỉ lệ người di cư biết đến là bệnh lây truyền qua đường tình dục còn thấp chỉ chiếm $40 \%$ ở mối giới. Ngoài các bênh kể trên thì có 3 người là từng nghe nói đến bệnh herpes.

\section{BÀN LUÂ̂N}

Kiến thức TDAT đạt chiếm $70,33 \%$ trên cả hai giới. Trong đó, nam chiếm tỷ lệ $68,97 \%$ và nữ chiếm 72,04\% cao hơn khá nhiều trên đối tượng nghiên cứu là nam, nữ di cư huyện Yên Phong, Bắc Ninh chỉ có $38,1 \%{ }^{5}$ hiểu đúng về tình dục an toàn và thấp hơn trên nghiên cứu của Phạm Thi Hương Trà Linh và Lã Ngọc Quang ${ }^{2}$ trền đối tượng là sinh viên trường Cao đẳng $\mathrm{Y}$ tế Phú Thọ có đến $86 \%$ sinh viên có kiến thức chung về TDAT đạt. Nguyên nhân là do trình độ học vấn của đối tượng nam, nữ di cư huyện Yên Phong thấp hơn nên có thể vốn kiến thức và khả năng hiểu câu hỏi thấp hơn đối tượng chúng tôi đang nghiên cứu, ngoài ra khu trọ của nam, nữ di cư trong $\mathrm{KCN}$ ở khá gần nhau, mỗi phòng trọ tập trung đông người nên có thể xảy ra việc các đối tượng tham gia nghiên cứu này trao đổi, chép đáp án của nhau cộng với sự lơi lỏng khi giám sát của giám sát viên. Còn ở nghiên cứu của Phạm Thị Hương Trà Linh và Lã Ngọc Quang trên đối tượng sinh viên y, đối tượng có kiến thức về sức khỏe tình dục và sức khỏe sinh sản cao hơn hẳn do thường xuyên được giảng dạy trên trường, lớp.

Hâuu hết đối tượng nghiên cứu đã được nghe nói về các bênh lầy truyền qua đường tình dục, chiếm 99,04\%. Chỉ có 2 người chưa nghe, biết về các bệnh này. Trong số đối tượng đã nghe, biết, bệnh lậu là bệnh LTQĐTD được nhiều người biết nhất, chiếm $89 \%$ ở nam và $90 \%$ ở nữ, tiếp đến là HIV/AIDS chiếm $87 \%$ nam, $89 \%$ nữ và giang mai chiếm $86 \%$ nam và $89 \%$ nữ. Kết quả này tương tự nghiên cứu của Lữ Thị Mai Oanh" 
có $83,5 \%$ công nhân di cư biết về bệnh giang mai, $79 \%$ bệnh lậu $77,5 \%$ HIV/AIDS là bệnh LTQĐTD, nhưng lại cao hơn nhiêu so với nghiên cứu của Nguyễn Thị Phương và Lê Cự Linh ${ }^{3}$, chỉ có hơn hai phần ba đối tượng được hỏi biết đến ba bệnh này. Phải chăng lao động tự do di cư hiện nay thường ít có cơ hội và nhu cầu tìm hiểu một cách nghiêm túc và đầy đủ thông tin về bệnh LTQĐTD.

Bất kỳ một căn bệnh nào cũng có nguyên nhân gây bênh của nó. Để hiểu rõ hơn về tính chất nguy hiểm của bệnh LTQĐTD, chúng tôi đã tiến hành khảo sát, phân tích mức độ hiểu biết của người di cư lao động tự do về nguyên nhân có thể mắc các bệnh LTQĐTD. Đa số đối tượng được hỏi biết về nguyên nhân mắc các bệnh LTQĐTD, $95 \%$ nam và $90 \%$ nữ cho rằng QHTD với người bị bệnh không dùng BCS là nguyên nhân dẫn đến mắc STIs chênh lệch không đáng kể so với điều tra di cư nội địa ${ }^{3}(89,2 \%)$ Tuy nhiên, các nguyên nhân khác lại chiếm tỷ lệ thấp hơn, có $80 \%$ nam và $82 \%$ nữ cho rằng $\mathrm{QHTD}$ với nhiều người không dùng BCS là nguyên nhân dẫn đến STIS, do sử dụng chung kim tiêm không tiệt trùng với người bệnh chiếm $54 \%$, tiếp xúc với máu, chất dịch của người bị bệnh chiếm $50 \%$ và truyền máu không an toàn là thấp nhất, chỉ chiếm $40 \%$, thấp hơn so với hai nghiên cứu trên. Như vậy, đa số nam, nữ di cư đã biết được những con đường chính sẽ dẫn đến lây truyền các bệnh LTQĐTD. Đặc biệt là việc không sử dụng bao cao su trong khi quan hệ tình dục với người nhiễm bệnh hoặc quan hể tịnh dục với nhiều người không sử dụng $B C S$, bởi đó là hành vi có nguy cơ lây truyền các bệnh LTQĐTD. Tuy vậy, có vẻ những đối tượng này cho rằng chỉ những nguyên nhân liên quan đến QHTD thì mới có khả năng gây bệnh LTQĐTD. Mặt khác, khi được hỏi về người có nguy cơ cao mắc các bệnh lây truyền qua đường tình dục và HIV/AIDS, câu trả lời hiểu được còn hạn chế. Chính vậy, biết được cách phòng tránh bệnh LTQĐTD càng vô cùng quan trọng và cấp thiết không chỉ cho bản thân mà còn với những người xung quanh. Nhưng thực tế thì không phải ai cũng biết điều đó, bằng chứng cho thấy, tỷ lệ đối tượng hiểu được luôn sử dụng BCS đúng cách khi QHTD chiếm $95,69 \%$ ở nam và $97,85 \%$ ở nữ, chỉ QHTD với một người chiếm 69,83\% nam và 63,44\% nữ, cão hơn đáng kể so với nghiên cứu của Nguyễn Lan $A^{6}{ }^{6}$ với $89 \%$ hiểu rằng luôn sử dụng BCS đúng cách khi QHTD, 42,8\% chỉ QHTD với một người. Tuy nhiên, hiểu biết về thời điểm dễ mang thai nhất nếu QHTD là giữa hai kỳ kinh không cao, đặc biệt ở nam chỉ có 38\% hiểu đúng, trong khi đó ở nữ chiếm tới $58 \%$ cao hơn kết quả nghiên cứu trên sinh viên ở Bắc Giang năm 2017 $(28,4 \%)^{7}$. Điều này có thể được giải thích bởi tỷ lệ đối tượng đã kết hôn trong nghiên cứu của chúng tôi là khá lớn nên sẽ dành sự quan tâm đến vấn đề tình dục an toàn nhiều hơn người chưa kết hôn. So với kết quả nghiên cứu của Nguyễn Thị Phương và Lê Cự Linh ${ }^{3}$ trên đối tượng nam công nhân di cư ở tỉnh Vính Phúc năm 2012 (18,2\%). Đây là điêu rất đáng lo ngại, lao động tự do di cư không có kiến thức về thời điểm mang thai có thể dẫn đến tình trạng mang thai ngoài ý muốn và nạo phá thai không an toàn nếu như đối tượng lựa chọn tính vòng kinh là biện pháp tránh thai duy nhất hoặc cho rằng đây là 1 biện pháp tránh thai có hiệu quả cao tương tự như sử dụng BCS hay uống thuốc tránh thai.

\section{KẾT LUẬN}

- Người di cư lao động tự do có kiến thức tình dục an toàn đạt khá cao, chiếm $70,33 \%$.

- Tỷ lệ người di cư lao động tự do hiểu đúng chưa cao về tình dục an toàn là không để mang thai ngoài ý muốn chỉ chiếm $(49,76 \%)$ và không để bị các bệnh lây truyền qua đường tình dục và HIV/AIDS $(62,68 \%)$. Tuy nhiên kiến thức về thời điểm dễ có thai nhất trong chu kỳ kinh nguyệt khá thấp (35\% nam và $58 \%$ nữ).

Lời cảm ơn. Chúng tôi xin chân thành cảm những người lao động di cư tự do sống trên địa bàn phường Hoàng Liệt, Quận Hoàng Mai đã tham gia nghiên cứu này.

Đây là công trình nghiên cứu của chúng tôi, chưa đăng bất kỳ trên các tạp chí nào nếu sai sót chúng tôi oàn toàn chịu trách nhiệm trước pháp luật.

\section{TÀl LIỆU THAM KHẢO}

1. Nguyễn Lan Anh. Kiến thức, hành vi về tình dục an toàn của sinh viên trường Cao Đằng nghề công nghể Việt - Hàn, tỉnh Bắc Giang, năm 2017. Luận văn tốt nghiệp, Đai học Y Hà Nội, Hà Nội. 2017.

2. Kết quả Tổng đîeu tra dân số và nhà ở năm 2019. UNFPA Viet Nam, https://vietnam. unfpa.org/ vi/news/kết-quả-tổng-điêu-tra-dân-sốvà-nhà-ở-năm-2019. Ngày cập nhật 19 tháng 12 năm 2019. Ngày truy cập 7 tháng 12 năm 2020.

3. Lữ Thị Mai Oanh. Nhận thức, thái độ, hành vi vê tình dục an toàn của cổng nhân ngoại tỉnh trên địa bàn Hà Nội hiện nay. Luận văn thạc sỹ, Đại học quốc gia Hà Nội - Đại học khoa học xã hội và nhẩn văn, Hà Nội. 2012.

4. Phạm Thị Hướng Trà Linh, Lã Ngoc Quang. Thực trạng và một số yêu tố liên quan đến hành vi tình dục của sinh viên trường Cao đăng $Y$ tế Phú Thọ, năm 201ㄴ. Tạp chí Y tế Công cộng. 2015. 34: 49-56.

5. Nguyển Thị Phương, Lê Cự Linh. Kiến thức, 
thái đô̂ và hành vi trong quan hệ tình dục ở nam công nhân chưa kết hôn di cư tai khu công nghiệp Bình Xuyên-tỉnh Vinh Phúc. Luận vẳn thạc sỹ Y tế Công cộng, Trường Đại học Y tế Công cộng, Hà Nội. 2012.

6. Tổng cuc dân số - Kế hoach hóa gia đình. Nôi dung chủ yếu về chiến lược dân số và sức khỏe sinh sản Viêt Nam giai đoan 2011-2020. 2011.

7. Website with no named author; no publication or accessed dates. Total number of international migrants at mid-year 2019. Migration Data Portal. https://migrationdataportal.org/?i=stock_abs_\&t= 2019. Updated date September 18, 2019. Accessed date December 7, 2020.

8. WHO. Report on global sexually transmitted infection surveillance 2018. Geneva: World Health Organization; 2018. Licence: CC BY-NC-SA 3.0 IGO] https://www.who.int/reproductivehealth/publ ications/stis-surveillance-2018/en/. Accessed date December 7, 2020.

\section{KẾT QUẢ SớM VÀ TRUNG HAN PHẪU THUÂT SỬA VAN HAI LÁ ÍT XÂM LẤN QUA ĐƯỜNG MỞ NHỎ NGỰC PHẢI TẠI BÊ̂NH VIỆN TIM HÀ NộI}

\section{Trần Lê Công Thắng1, Nguyễn Sinh Hiền ${ }^{1,2}$, Nguyễn Minh Ngọc $^{2}$}

\section{TÓM TẮT}

Nghiên cứu hồi cứu mô tả 45 bênh nhân được phẫu thuât sửa van hai lá ít xâm lấn với nôi soi hỗ trợ tại Bệnh Viện Tim Hà Nội từ tháng 01/2018 đến tháng $12 / 2020$, với thời gian theo dõi sau mổ kéo dài trung bình 16,4 tháng. Tuổi trung bình là $49 \pm 12,5$ tuổi. Ti lệ nam/nữ xấp xỉ 1/1. Trong đó có 43 trường hợp van thoái hóa, 2 trường hợp van hậu thấp. Cơ chế chính là tổn thương lá sau (34 trường hợp), đứng thứ hai là tổn thương cả lá trước và lá sau có 7 trường hợp; tổn thương lá trước đơn thuần gồm 4 trường hợp. Thời gian chạy máy TNHCT $164 \pm 34$ phút, thời gian cặp đông mach chủ $93 \pm 19$ phút. Kỹ thuất tao hình van hai lá bao gồm: đặt vòng van $100 \%$, cắt tam giác/ tứ giác/ butterfly $48,9 \%$, khâu gấp nếp lá sau $24,4 \%$, dây chằng nhân tạo $20 \%$, edge-to-edge $13,3 \%$. Tỉ lệ tử vong trong bênh viện và 30 ngày sau mô là $0 \%$. 4 trường hợp có biến chứng trong đó bao gồm 2 trường hợp chảy máu phải mổ lại, 1 trường hợp tràn dịch màng phổi cần dẫn lưu $(2,2 \%), 1$ trường hợp nhiễm trùng vết mổ đùi sau mổ $(2,2 \%)$, không có trường hợp nào phải mổ lại thay van trong hoặc trong khi nẳm viện. Thời gian hồi sức trung bình $2,5 \pm 0,7$ ngày, thời gian thở máy $18.9 \pm 7,5$ giờ. Tất cả $45 \mathrm{ca}$ đều được phẫu thuật thành công, không có trường hợp nào phải mở rộng đường mở ngực hay chuyển mở xương ức. Tỉ lệ sửa van hai lá thành công cao (không hở hoăc hở đô I trên siêu âm sau mổ) $(95,6 \%)$

Tư khoá: phẫu thuật sửa van hai lá ít xâm lấn, đường mở nhỏ ngực phải.

\section{SUMMARY \\ EARLY AND MID-TERM OUTCOMES IN \\ MINIMALLY INVASIVE MITRAL VALVE REPAIR VIA RIGHT MINITHORACOTOMY AT HANOI HEART HOSPITAL}

\footnotetext{
${ }^{1}$ Trường Đại học Y Hà Nội

${ }^{2}$ Bênh viên Tim Hà Nôi

Chịu trách nhiệm chính: Trần Lê Công Thắng

Email: thang.otso@gmail.com

Ngày nhận bài: 2.8.2021

Ngày phản biên khoa hoc: 1.10 .2021

Ngày duyệt bài: 7.10.2021
}

This was a hospital-based cohort study including 45 retrospective patients who underwent minimally invasive mitral valve repair with endoscopic support at Hanoi Heart Hospital from January 2018 to December 2020, with prolonged postoperative follow-up. average 16.4 months. The mean age was $49 \pm 12.5$ years old. The male/female ratio is approximately $1: 1$. Patients with mitral valve repair included 43 degenerative valves, 2 post rheumatic valves. The main mechanism is damage to the posterior leaves (34 cases), the second is damage to both the anterior and posterior leaves in 7 cases; simple anterior leaf lesions include 4 cases. Cardiopulmonary bypass and aortic clamp times were $164 \pm 34$ and $93 \pm 19$ minutes. Mitral valve reshaping techniques include: annuloplasty $100 \%$, leaflet resection $48.9 \%$, folding $24.4 \%$, neochordae implantation $20 \%$, edge -to- edge $13.3 \%$. Overall, inhospital and 30-day mortality were $0 \%$. We encountered 4 complications including 2 cases of bleeding requiring reoperation, 1 case of 1 pleural effusion $(2.2 \%)$, 1 case of postoperative thigh infection (2.2\%). The ICU length of stay was $2.5 \pm 0.7$ days, and average time to extubation was $18.9 \pm 7.5$ hours. All 45 cases were successfully operated, there were no cases that had to widen the thoracotomy or sternotomy. The success rate of mitral valve repair is high. (95.6\%).

Keywords: Minimally invasive mitral valve repair, minithoracotomy.

\section{I. ĐĂTT VẤN ĐỀ}

Kể từ năm 1996, lần đầu tiên Carpentier đã thành công trong phẫu thuật van hai lá qua đường mở ngức nhỏ có nôi soi hỗ trơ cho đến nay, hơn 20 nằm qua, các bác sĩ phẫu thuật tim mạch trên thế giới đã và đang phát triển và hoàn thiện kĩ thuât trong lĩnh vực phẫu thuât ít xâm lấn. Kỹ thuẩt mổ này đã chứng minh được những ưu điểm như tính an toàn, tỷ lệ tử vong sau mổ thấp, giảm sang chấn, ít đau, ít chảy máu, giảm thời gian thở máy, hồi sức và nằm viên, tính thẩm mỹ cũng như giảm thiểu tỷ lê nhiếm trùng vết mổ và các biến chứng liên quan 